\title{
Innovation mode of College English classroom teaching under the new curriculum reform
}

\author{
HuDan \\ Nanchang Institute of Science \& Technology, Nanchang 330108,China
}

Key words: new curriculum reform; English classroom; teaching innovation

\begin{abstract}
Starting from the innovative teaching mode of College English classroom, this article mainly has analyzed the present situation and the existing college English, and according to the requirements of the new curriculum reform, innovation and exploration has been carried out in the College English classroom teaching mode, teaching aids and teaching evaluation form, which provides a feasible way to realize the English Classroom Teaching and the realization of national education reform.
\end{abstract}

\section{Introduction}

With the continuous progress and development of the times, the traditional classroom teaching model has been unable to meet the needs of modern teaching, the new curriculum reform has put forward new requirements for College English classroom teaching. In order to improve the teaching quality of College English classroom fundamentally, College English teachers need to actively explore new teaching methods, and improve the quality of teaching, then really meet the actual needs of College English classroom, according to the new the teaching goal and the teaching content to choose appropriate teaching methods,. Therefore, according to the requirements of the new curriculum reform, the teaching of College English class should be innovated from the teaching method, and then the teaching level can be improved effectively.

\section{The present situation and problems of College English Teaching}

College students English level is not consistent. Before the college entrance examination reform, colleges and universities in China are based on the total score of the college entrance examination to decide whether to admit the student, there is no clear limit of English scores, resulting in college students' English level uneven, thus affects college English teaching teachers. After the 2017 implementation of the reform policy of college entrance examination, students will be admitted to the university according to the students' English scores, this move will make English level of students entering the same college relatively balanced. In the transition period of college entrance examination policy reform, it obviously can not meet the needs of modern education if the College English teachers still adopt the previous teaching mode, and not to explore new teaching methods.

College students' oral English is poor generally. The traditional English teaching mode mainly is examination oriented teaching mode, students tend to focus on the study of English grammar, and ignore oral English practice, students can only do, and not in English oral expression.

Oral English teaching has always been a weak link in College English teaching. Due to the lack of practice of oral English in the environment and opportunities, many students have a poor foundation of the English phonetic alphabet, pronunciation is not standard, leading students to communicate with others in English. Because of the poor foundation of students' spoken English, oral English teaching is a problem which is difficult to solve in the English class of college.

College English teaching mode is single. Now most of the College English teaching mainly by 
teachers to impart knowledge to students, most of the time in the classroom is the teacher to explain the knowledge points, lack of communication and interaction with students, leading to a student-centered class to the teacher as the main classroom. This kind of teaching mode to a certain extent, the enthusiasm of the students to learn English, and even have a weary English. Although in recent years, College English classroom has gradually combined with the use of multimedia, but it has not been able to play its due role, nor to achieve the purpose of improving teaching efficiency. In the English class, there is no chance to communicate with each other in English, and there is no chance to practice English.

\section{The necessity of College English classroom innovation under the new curriculum reform}

The need of present College English classroom situation. Although the teaching reform of College English education practice for many years, but also effectively implement the teaching reform ideas, but no improvement in College English classroom and single teaching method in classroom teaching of College English practical in some teachers are also actively explore diversified teaching mode, but there was no significant effect of the students thinking innovation competence has not been effectively explored. Therefore, teachers in Colleges and universities should keep up with the trend of the times, improve their own quality level, scientifically and effectively deal with the relationship between teaching and learning, and realize the diversification of teaching mode.

The need of students' psychological development. College students have a high degree of independence and critical thinking, can be analyzed from many aspects and angles. Therefore, college teachers should be fully aware that English classroom teaching is the teachers and students mutual exchange of learning process, the only fully understand the psychology of the students, to develop scientific and reasonable teaching strategy, improve college English teaching level and teaching quality. Under the background of the new curriculum reform, teachers need to break the traditional teaching mode, build a new teaching class, meet the actual needs of the students, and provide more qualified talents for the society. College teachers should actively explore innovative and heuristic teaching methods to adapt to the development of students' physical and mental development.

The need of college enrollment system. In recent years, the society pays more and more attention to higher education and talent training, the introduction of the college entrance examination system, can provide more potential for college students, as long as the reasonable development of their talents to the society, can provide high-quality. For example, the college entrance examination enrollment system more and more fair and humane. The age limit of the candidates is relaxed, while the candidates have the right to parallel volunteer, so that the chances of admission of students has been greatly improved. At the same time, many colleges and universities have also implemented a college enrollment plan, there are independent recruitment of qualified colleges and universities can be less than $0.5 \%$ of the enrollment plan in the year, through the independent recruitment of candidates with special abilities. The continuous innovation and development of the college entrance examination system is conducive to the development of students' personality. The teaching class in Colleges and universities should be based on students, respect for the differences between students, to create an open learning environment and learning atmosphere for students, and promote the all-round development of students. 


\section{Exploration and analysis of College English teaching innovation model}

Play the main role of the students in the classroom. Students are the masters of learning, therefore, in the process of College English teaching, teachers must actively guide students to participate in classroom learning, maximize their learning initiative. To make students become the discoverer and creator of knowledge, so as to cultivate students' innovation consciousness in College English teaching. In order to achieve this goal, which requires teachers to put the initiative back to students, let students can autonomously learn, teachers need to do is to seize the key points of knowledge on demand, in order to pave the way for students' Autonomous learning. Through the active exploration of students, students can stimulate the enthusiasm of learning, so that students have a stronger learning motivation.

Combine information technology to improve classroom efficiency. With the growing popularity of information technology, classroom content has been limited to the textbooks, teachers should take the textbook based, supplemented by audio-visual materials and electronic materials, the use of information technology to be more vivid, activities in the form of knowledge will be presented to the students, arouse students' passion for learning English, it also can promote students' autonomy exploration and research. The teacher can also create a network communication platform using information technology, students can use computer and mobile phone network platform to interact with others in English, oral practice, offers students a chance to practice spoken English and create atmosphere. The new curriculum reform requires us to combine the information technology and the curriculum in the teaching process. With the development of the teaching software, multimedia, network technology is widely used in the teaching process of College English teacher, which also put forward higher requirements, the use of information technology to obtain knowledge of College English teachers can correctly and effectively, and make the electronic courseware high level, in order to extract high quality English teaching.

Optimize teaching evaluation system. Study of the traditional mode of teaching evaluation of a student is to pass the final exam scores to evaluate, but no comprehensive evaluation of all aspects of students, ignoring students' ability, quality evaluation, social activities etc., inflexible evaluation methods, is not conducive to the development of students, hit the learning the enthusiasm of many college students. However, in the context of the new curriculum reform for a student evaluation is not limited to the test scores of the students, but also pay attention to students' quality, self-learning ability, cooperation ability, cooperative learning ability, explore innovative ability, innovation ability, thinking quality and other aspects of the comprehensive evaluation to the vision of development to evaluate students, pay attention to the cultivation of students' practical ability, practical ability, innovation ability, but not to a test score evaluation of the students' success, evaluation methods should be scientific, comprehensive, objective, to be conducive to the healthy development of students. In short, the learning process should be a happy process, effectively improve the efficiency of College English classroom teaching, entertaining, to enable students to understand the learning fun, so as to realize the purpose of our new curriculum reform.

\section{Conclusion}

College English teaching is facing many challenges Under the new curriculum reform, the change of some teaching models and teaching ideas, both for students and teachers, need a process to adapt to the change, but at the same time, this is also a good opportunity for College English classroom to promote the reform and innovation. Under the background of the new curriculum reform, new 
teaching models and teaching programs are emerging, which is gradually changing the current situation of English Teaching in Colleges and universities in our country. But the innovation of teaching method can not be achieved at once, Teachers are needed to continue to explore in the process of teaching practice, constantly sum up, continuous improvement, making teaching methods more and more perfect, so that the students can learn the knowledge happily.

\section{Reference}

[1] Mao Ning. Based on the background of the new curriculum reform of college classroom teaching [J]. Journal of Hubei Correspondence University, Vol.17, (2016), p.145-146.

[2] Mou Changqing. Application of “flipped classroom” model in College English Listening Teaching [J]. Journal of Seeking Knowledge Guide, No.08, (2016), p.127

[3] Cui Huixia. How to realize the innovation of teaching methods in senior high school English class [J]. English Square, No. 04, (2016), p. 165-166.

[4] Yu Miao. College Research on the dilemma of English teaching reform in Colleges and universities in the new era [J]. Heilongjiang Science, No.08, (2015), p.114-117

[5] Liu Jingwen. Investigation and Study on the ability of independent inquiry teaching for English Majors in Higher Vocational Colleges [D]. Shandong Normal University, (2015)

[6] Lei Junyan. Research on the application of inquiry teaching in senior high school English Reading Teaching [D]. Shaanxi Normal University, (2014)

[7] Sun Qiuying. Analysis of the present situation and the problems of College English teaching[J]. Science \& Technology Vision, No.08, (2014), p. 157-238

[8] Tai Xi. Analysis of the innovation of College English listening and speaking teaching model [J]. Ability and Wisdom, No. 06, (2014), p. 91 (in Chinese)

[9] Wan Xintong. Innovation of English Teaching method under the new curriculum reform [J].Shaanxi Education (Higher Education), Vol. Z1 (2013), p. 92-93.

[10] Hu Wenjuan. How to stimulate students' interest in learning English under the new curriculum concept [J]. Educational Teaching Forum, Vol. S5, (2012), p. 118-119.

[11] Liu Li. On the role of students in Higher Vocational English teaching [J]. Modern Communication, No.04, (2011), p.177

[12] Huang Zhonghui. How to promote the subjectivity of students in English Teaching [J]. Read and Write Periodical, No.04, (2011), p. 111

[13] Yang Yanping. Return to the standard of student evaluation, p. the full development of students [J]. New Curriculum Research (Basic Education), No.06, (2010), p. 14-15.

[14] Yin Xiaolin. The application of cooperative learning in College English Intensive Reading [D]. Southwestern University, (2010)

[15] Li Chunfang. Research and Exploration on the reform of Public English teaching model [J]. Contemporary Continuing Education, (2008), p. 75-77.

[16] Dai Liping. Study on the strategies of promoting the autonomous learning of senior high school students under the new curriculum standard [D]. Guangxi Normal University, (2004) 